2017-08-01

\title{
An integrated approach for the planning of dredging operations in estuaries.
}

Alvarez, M

http://hdl.handle.net/10026.1/9400

10.1016/j.oceaneng.2017.05.014

Ocean Engineering

All content in PEARL is protected by copyright law. Author manuscripts are made available in accordance with publisher policies. Please cite only the published version using the details provided on the item record or document. In the absence of an open licence (e.g. Creative Commons), permissions for further reuse of content should be sought from the publisher or author. 
"This is the author's accepted manuscript. The final published version of this work (the version of record) is published by Elsevier B.V. in Ocean Engineering, 140, pp. 73-87, August 2017, available at: https:// doi.org/10.1016/j.oceaneng.2017.05.014. This work is made available online in accordance with the publisher's policies. Please refer to any applicable terms of use of the publisher."

1

2

3

$4{ }^{a}$ Univ. of Santiago de Compostela, Hydraulic Eng, EPS, Campus Univ. s/n, 27002

5 Lugo, Spain

$6{ }^{\mathrm{b}}$ Univ. of Plymouth, School of Marine Science and Engineering, Marine Building,

7 Drakes Circus, Plymouth PL4 8AA, United Kingdom

8 ABSTRACT

9 Ports are often located in naturally sheltered areas such as estuaries. The strong tidal
AN INTEGRATED APPROACH FOR THE PLANNING

\section{OF DREDGING OPERATIONS IN ESTUARIES}

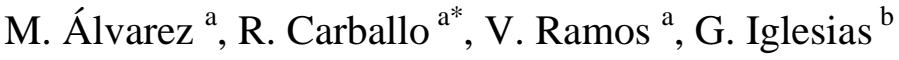

currents that occur in many of these areas drive a dynamic morphodynamic regime, with the result that the approach channels to these ports are gradually infilled. Periodic dredging is therefore necessary to maintain the operativity of the port. A case in point is Ribadeo (NW Spain), an important port for the economy of the area. In this work, the sediment transport patterns of the estuary (Ria de Ribadeo) are investigated through high-resolution numerical modelling and field measurements covering a 4-year period. On this basis, a decision-aid tool is developed that enables to predict the time evolution of the approach channel and thus contributes to the planning of dredging operations and, more generally, the maintenance of adequate operativity levels in a cost-effective way.

Keywords: estuary; dredging; port; sediment transport; navigation channel; numerical modelling.

*Corresponding author. Tel.: +34 982 285900; fax: +34 982 285926. E-mail address: rodrigo.carballo@usc.es (R. Carballo). 


\section{INTRODUCTION}

24 Shipping may be affected by a number of coastal processes (López and Iglesias, 2013;

25 López et al., 2015; Teodoro et al., 2014; Rosa-Santos et al., 2009), not least sediment

26 transport and its repercussions on restricted or semi-restricted navigation channels.

27 Sediment infilling may affect port operativity by limiting the time for vessels to access,

28 or depart from, a port. This is the case of a number of ports located in rias in Galicia

29 (NW Spain).

30 A ria is a particular type of estuary: a drowned river valley in which the accumulation of

31 sediment since the Holocene transgression has not kept pace with sealevel rise, and

32 therefore the bathymetry reflects closely the topography of the original river valley.

33 Galician rias are generally characterised as positive, partially mixed estuaries (Iglesias

34 et al., 2008).

35 The Port of Ribadeo is located in the middle section of the Ribadeo ria (in the

36 vernacular, Ria de Ribadeo or Ria del Eo, after the name of the river), at $43^{\circ} 32.865^{\prime} \mathrm{N}$,

$37007^{\circ} 02.054^{\prime} \mathrm{W}$ (Figure 1), and is the largest in trade volume of all the ports managed by the Regional Port Authority (Ports of Galicia). It has a great importance for the local and regional economy, with a hinterland exceeding a radius of $50 \mathrm{~km}$ from the port, which generates a considerable Short Sea Shipping. 
(a)

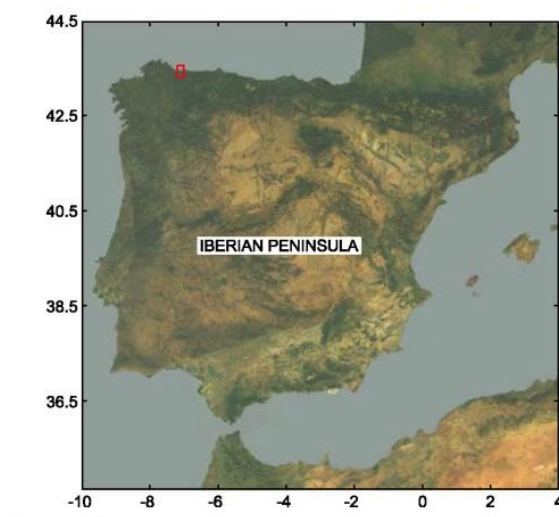

롱

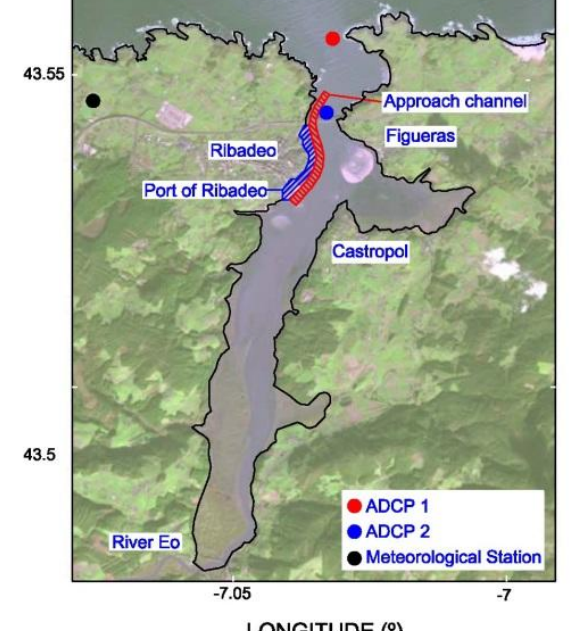

(c)

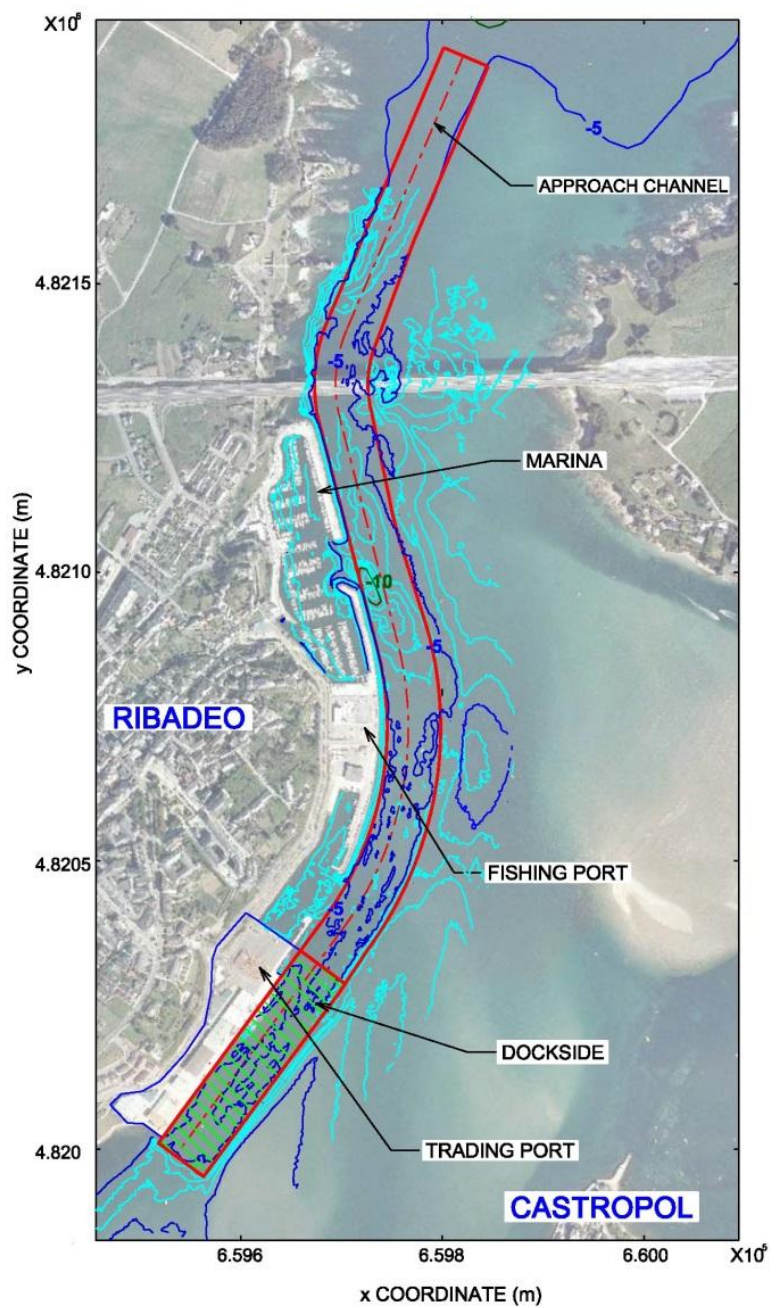

Figure 1. Location of Ría de Ribadeo (b) and Port of Ribadeo (c) in NW Spain (a).

The strong tidal currents in the Ria of Ribadeo (up to $2 \mathrm{~ms}^{-1}$ ) and the resulting residual circulation patterns (Ramos et al., 2013) cause large amounts of sediments to be transported, steadily infilling the approach channel to the Port of Ribadeo. A reduction in depth in the approach channel means that larger tidal levels are required for ships to access the Port, thereby limiting the operativity of the port and, consequently, threatening the economic activity in the area (García-Morales et al., 2015). For this reason, the port authority undertakes periodic dredging of the approach channel so as to maintain operativity. 
The aim of this work is to define a new integrated approach for the analysis of dredging operations in shallow coastal areas, such as estuaries, allowing the definition of an appropriate plan ensuring an adequate operativity at lower maintenance costs. With this aim, firstly, in Section 2, the requirements of the approach channel to the Port of Ribadeo are thoroughly defined. Next, in Section 3, high-resolution numerical simulations based on accurate field measurements are conducted covering a 4-year period. In Section 4, the tidal levels at the Port of Ribadeo computed through numerical modelling are analysed. Then, the results obtained in the aforementioned sections are combined leading to a decision-aid tool for the planning of dredging operations. Finally, in Section 5 the main conclusions of this work are presented.

\section{REQUIREMENTS OF THE APPROACH CHANNEL}

\subsection{Determining factors}

A correct definition of the geometry of the approach channel and harbour basin of a port located in a depth-limited area is of great importance for its appropriate functioning. The requirements for these areas are calculated in the present work for the Port of Ribadeo following a comprehensive methodology based on the Recommendation for Design of Maritime Configuration of Ports, Approach Channels and Harbour Basins (Puertos del Estado, 1999b; Álvarez, 2013).

The geometric definition of the navigational channel and harbour basin, both in terms of cross section and layout, should be based on a thorough knowledge of: i) the area occupied by the vessel (Sutulo et al., 2010; Briggs et al., 2015), which depends on the vessel dimensions, ii) the different factors affecting its movements, iii) and the water level. Furthermore, in the study area it is necessary to consider that the orientation of the 
approach channel is similar to that of the breakwaters and dock of the Commercial Port of Ribadeo (Figure 1), and their foundations are at $-5.00 \mathrm{~m}$ relative to the datum (LAT, lowest astronomical tide); therefore, the maximum dredging depth relative to the datum should not exceed $5 \mathrm{~m}$ to avoid undermining the structures. This is indeed the depth at which the approach channel is currently dredged during maintenance operations, and the depth retained for the following analysis.

In the present study the cross section and layout requirements are defined based on the design vessel, i.e. the vessel which best represents the different types of vessels operating in the area of interest. With this aim, a comprehensive study of the shipping at the Port of Ribadeo was conducted. In total, during 2014 a total of 176 vessels operated at this Port, of which 158 were of general cargo, the remaining being composed of nine passenger ships, 4 gearless container vessels, 4 research vessels, 3 fishing trawlers and 1 bulk carrier. After a thorough analysis of the characteristics of the different types of vessels, the design vessel at this Port is defined. Its characteristics are shown in Table $\mathbf{1 .}$

[TABLE 1]

Table 1. Characteristics of the design vessel at the Port of Ribadeo

\begin{tabular}{|c|c|}
\hline Parameter & Measure \\
\hline Gross Tonnage & $2,700 \mathrm{GT}$ \\
\hline Length & $90 \mathrm{~m}$ \\
\hline Length between perpendiculars & $85 \mathrm{~m}$ \\
\hline Draught & $5.72 \mathrm{~m}$ \\
\hline Deep load draught & $5.41 \mathrm{~m}$ \\
\hline Moment of inertia & $11,449 \mathrm{~kg} \mathrm{~m}^{2}$ \\
\hline Freeboard & $1.79 \mathrm{~m}$ \\
\hline Depth & $7.2 \mathrm{~m}$ \\
\hline
\end{tabular}




\subsection{Cross-section requirements}

94 The cross section of a channel is sometimes designed in a deterministic way, i.e. on the

95 basis of a single parameter (i.e. the draught of design vessel); it is more adequate, 96 however, to take into account a number of factors (Puertos del Estado, 1999a) (Figure $972)$.

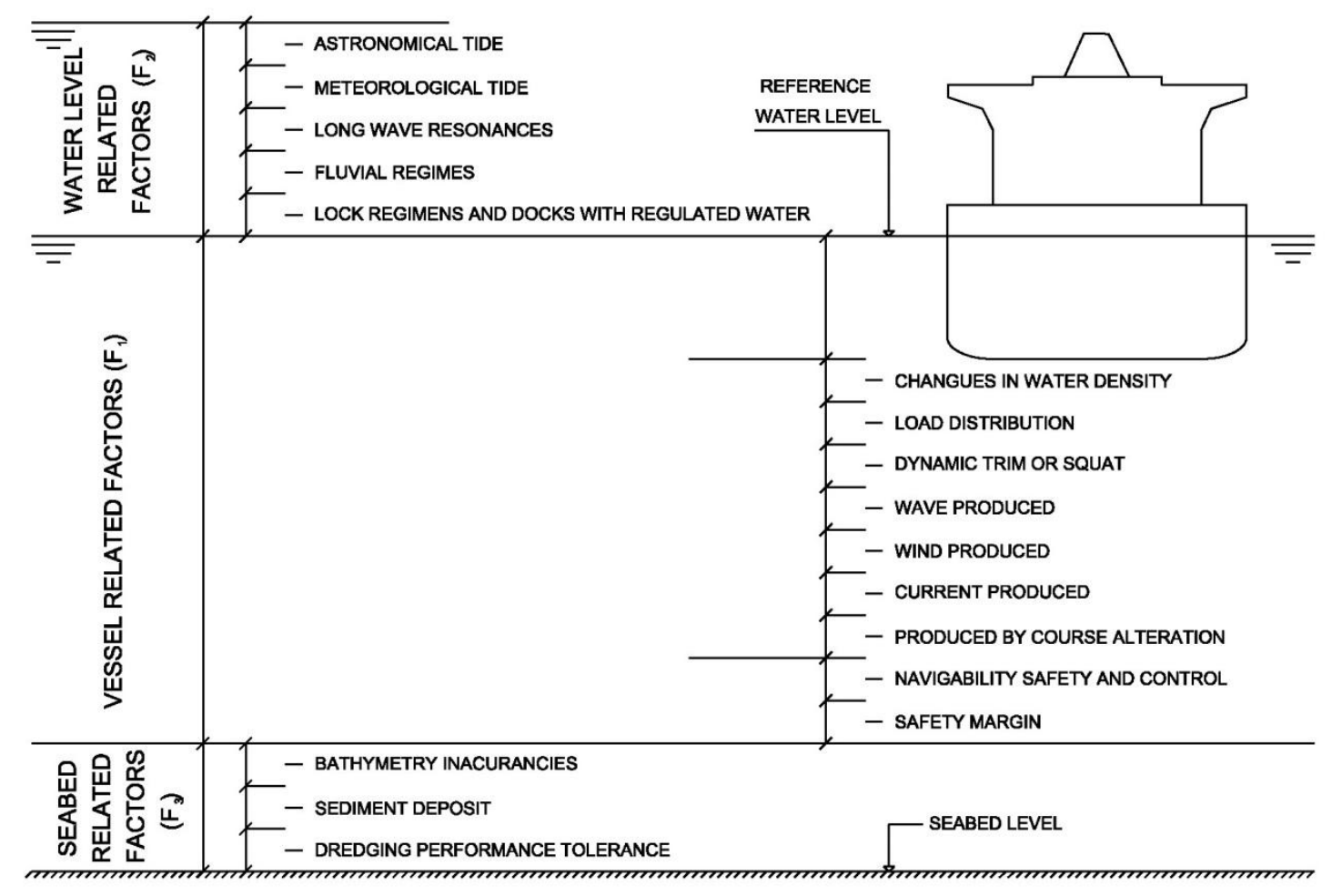

100 Figure 2. Sketch showing the factors considered in the design of the cross section of the approach channel. [Source ROM 3.1 99 Part VII].

102 The first set of factors, represented by $F_{1}$, integrates all the factors depending on the

103 vessel itself. It represents the lowest level that any point of the vessel can reach in 104 relation to the mean level of the water where it is located. For the definition of $F_{1}$, in the 105 present work a thorough study of the sea conditions in the area is conducted (Álvarez, 

2013). This information combined with the characteristics of the design vessel allows

107 the computation of $F_{1}$. The second set of factors, represented by $F_{2}$, provides an analysis 108 of the tides and other variations in the mean water level (astronomical and 109 meteorological tides, variations in river flows, etc...), i.e. a factor determining the 110 reference level of the water where the vessel is located. This is a key factor given that in 111 the case of a vessel with specific depth requirements (larger than $5 \mathrm{~m}$ depth in the 112 present application), a certain tidal level is required for them to operate in the area. 113 Finally, $F_{3}$ includes the last set of factors depending on the seabed, including 114 bathymetry inaccuracies, sediment deposits and dredging performance tolerances 115 (Álvarez, 2013). The values of the different factors considered in the present work are 116 summarised in Table 2. 
128 Table 2. Parameters for prevention of grounding in the channel

\begin{tabular}{|c|c|c|}
\hline \multicolumn{2}{|c|}{ PARAMETERS } & VALUE (m) \\
\hline \multirow{8}{*}{$\begin{array}{l}\text { Vessel } \\
\text { related factors }\left(\mathrm{F}_{1}\right)\end{array}$} & Static draught & 5.41 \\
\hline & $\begin{array}{l}\text { Additional draught due to changes } \\
\text { in water density }\end{array}$ & 0.16 \\
\hline & $\begin{array}{l}\text { Additional draught due to cargo } \\
\text { distribution }\end{array}$ & 0.20 \\
\hline & Dynamic trim or squat & 0.62 \\
\hline & Motions caused by waves & 0.10 \\
\hline & Heeling caused by wind & 0.08 \\
\hline & $\begin{array}{l}\text { Clearance for safety control of the } \\
\text { vessel's maneuverability }\end{array}$ & 0.5 \\
\hline & Total $\left(\mathbf{F}_{1}\right)$ & 7.07 \\
\hline \multirow{2}{*}{$\begin{array}{l}\text { Water level } \\
\text { related factor }\left(\mathrm{F}_{2}\right)\end{array}$} & Astronomical tide & Variable \\
\hline & Total $\left(\mathbf{F}_{2}\right)$ & $F_{1}+F_{3}$-channel depth \\
\hline \multirow{4}{*}{$\begin{array}{l}\text { Seabed } \\
\text { related factors }\left(\mathrm{F}_{3}\right)\end{array}$} & Margin for bathymetry inaccuracies & 0.07 \\
\hline & Deposit of sediments & Variable (0 after dredging) \\
\hline & Dredging performance tolerance & 0.37 \\
\hline & Total $\left(\mathbf{F}_{3}\right)$ & 0.37 \\
\hline
\end{tabular}

130 The required water depth will be the result of considering both the vessel and seabed

131 related factors, $F_{1}$ and $F_{3}$, respectively. Therefore, a total of $7.44 \mathrm{~m}$ is required for the

132 design vessel to access or leave the Port of Ribadeo. Given that the water depth of the

133 approach channel for operation purposes at LAT is set to $5 \mathrm{~m}$, the required tidal level or $134 \quad F_{2}$ is $2.44 \mathrm{~m}$. 


\subsection{Layout requirements}

138 The layout of the channel has to be adapted to the local morphological aspects, as well 139 as to technical, economic and environmental constraints. In the case of the Port of 140 Ribadeo, the approach channel has a total length of $2,262 \mathrm{~m}$ in three straight and two 141 curved stretches. The two curved stretches have a radius, $r$, of $260.5 \mathrm{~m}$ and $639 \mathrm{~m}$, 142 respectively. For technical and safety reasons the approach channel to this port consists 143 of a single lane fairway whose requirements are calculated in the present study for the 144 design vessel.

145 As a result of the implementation of the aforementioned methodology the overall width 146 of the fairway is set to $90 \mathrm{~m}$ and $100 \mathrm{~m}$ in straight sections and curves, respectively. 147 Finally, due to the presence of moorings lines in the dockside, the straight section in this area is increased $15 \mathrm{~m}$ (Álvarez, 2013). The cross section and layout requirements thus obtained are shown in Figure 3 and the resulting plan view of the area occupied by the approach channel in Figure 4.

151

152

153

154

155

156

157 
CROSS SECTION A-A' AND C-C'

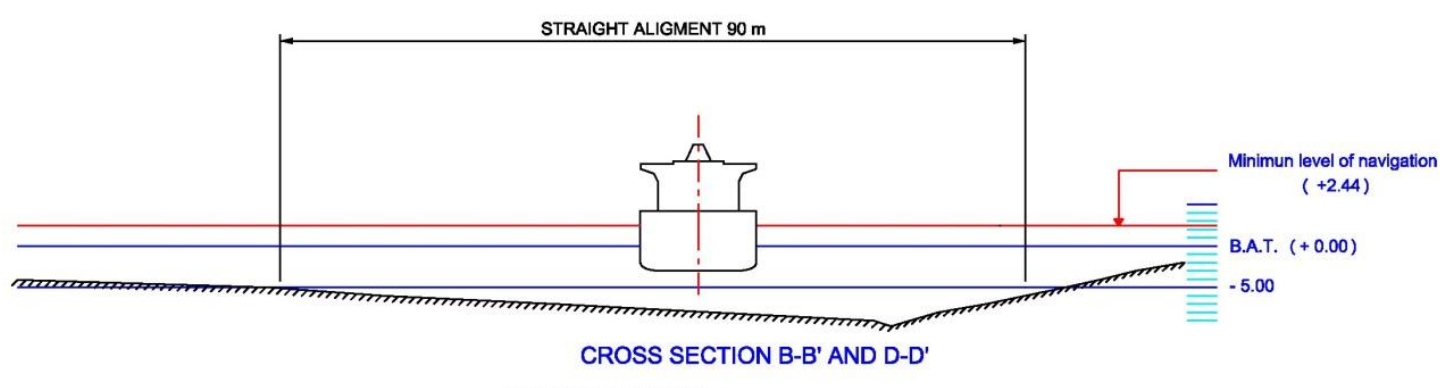

CURVE ALIGNMENT $100 \mathrm{~m}$
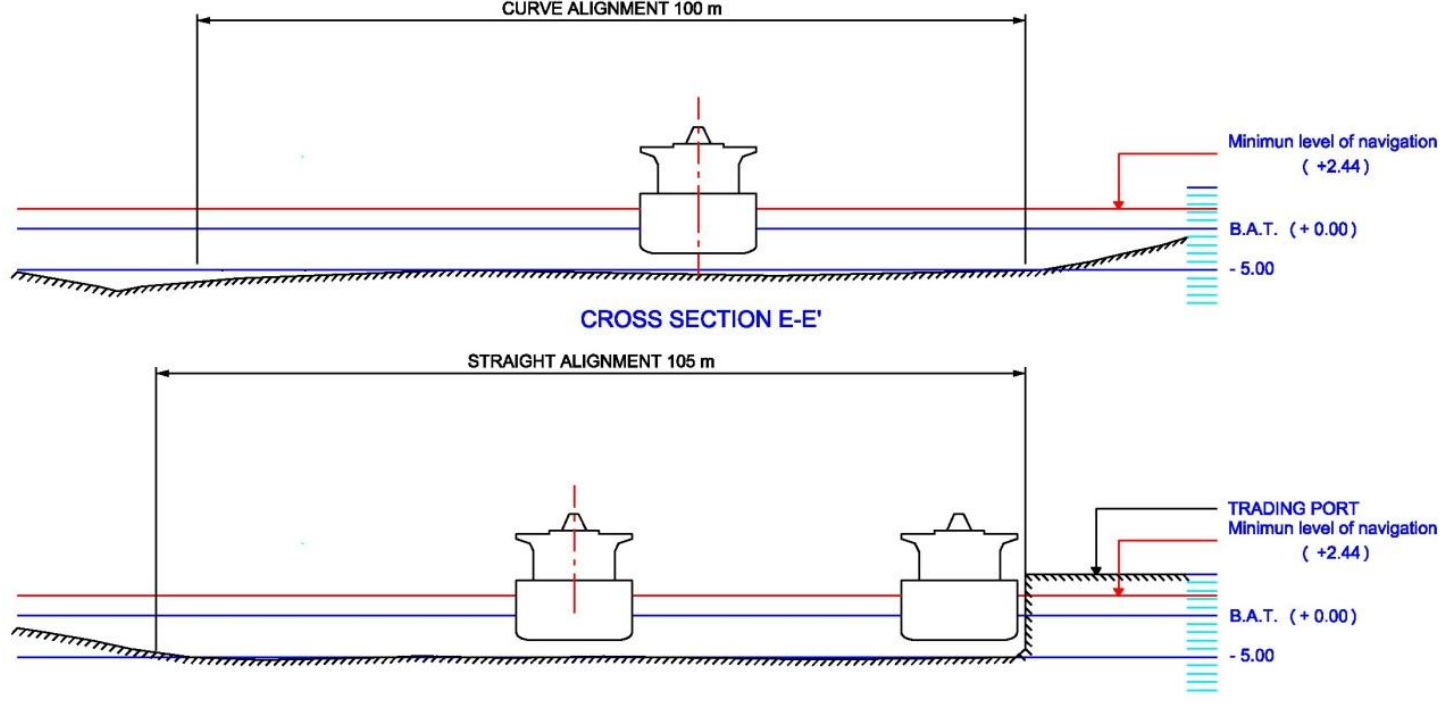

160

161 Figure 3. Cross section and layout requirements of the approach channel to the Port of

162 Ribadeo.

163

164

165

166

167 


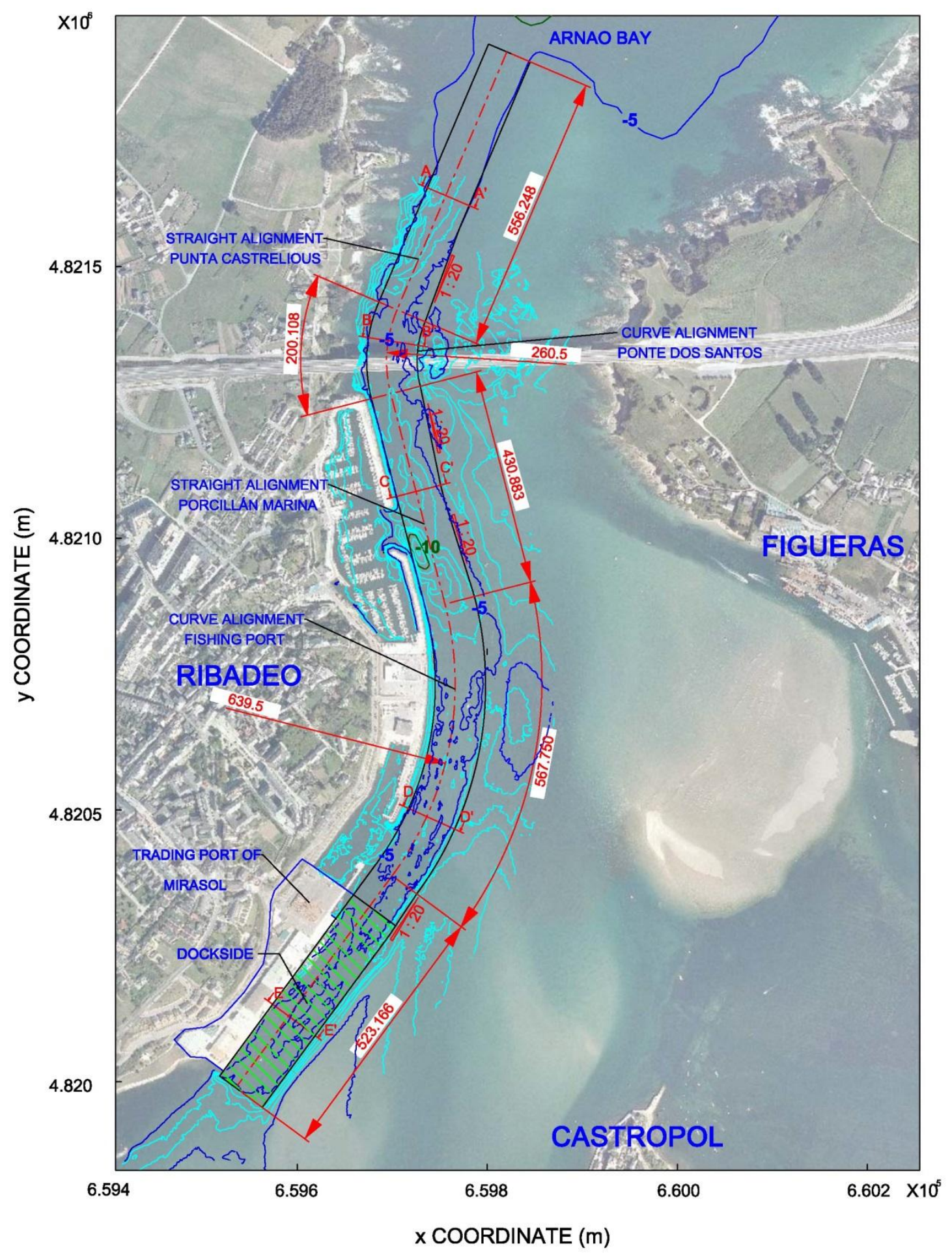

171 Figure 4. Plan view representation of the area occupied by the approach channel. 


\section{NUMERICAL MODEL}

174

175

176

177

179

180

181

182

$184 \frac{\partial u}{\partial x}+\frac{\partial v}{\partial y}+\frac{\partial w}{\partial z}=Q$

185

$$
\frac{D u}{D t}=f v-g \frac{\partial \zeta}{\partial x}-\frac{g}{\rho_{0}} \int_{z=z}^{z^{\prime}=\varsigma} \frac{\partial \rho}{\partial x} d z^{\prime}+v_{h}\left(\frac{\partial^{2} u}{\partial x^{2}}+\frac{\partial^{2} u}{\partial y^{2}}\right)+v_{v}\left(\frac{\partial^{2} u}{\partial z^{2}}\right)
$$

$\left.\frac{D v}{D t}=-f u-g \frac{\partial \zeta}{\partial y}-\frac{g}{\rho_{0}} \int_{z^{\prime}=z}^{z^{\prime}=\varsigma} \frac{\partial \rho}{\partial y} d z^{\prime}+v_{h}\left(\frac{\partial^{2} v}{\partial x^{2}}+\frac{\partial^{2} v}{\partial y^{2}}\right)+v_{v}\left(\frac{\partial^{2} v}{\partial z^{2}}\right)\right\}$

$186 \frac{\partial p}{\partial z}=-\rho g$

187

$$
\frac{D c}{D t}=D_{h}\left(\frac{\partial^{2} c}{\partial x^{2}}+\frac{\partial^{2} c}{\partial y^{2}}\right)+D_{v} \frac{\partial^{2} c}{\partial z^{2}}-\lambda_{d} c+R
$$

where $u, v$ and $w$ represent the components of the velocity in the directions $x, y$ and $\mathrm{z}$, respectively; $Q$ represents the sources of mass per unit area; $f$ is the Coriolis parameter; $g$ is the gravitational acceleration; $\zeta$ is the free surface elevation relative to $z=0 ; v_{h}$ and 
$191 v_{v}$ stand for the horizontal and vertical kinematic eddy viscosity coefficients,

192

200

201

202

203

204

205

206

207 respectively; $\rho$ and $\rho_{0}$ are the water density and the reference density of sea water, respectively; $c$ represents the mass concentration of any constituent (e.g. salinity and temperature); $D_{h}$ and $D_{v}$ stand for the horizontal and vertical eddy diffusivity coefficients, respectively; $\lambda_{d}$ represents the first order decay process; finally, $R$ is the source term per unit area.

In addition, the model computes sediment transport and morphological updating by simulating both bed-load and suspended load transport. In the case of suspended load, the advection-diffusion equation (mass balance) is solved, which reads:

$$
\frac{\partial c^{(l)}}{\partial t}+\frac{\partial u c^{(l)}}{\partial x}+\frac{\partial v c^{(l)}}{\partial y}+\frac{\partial\left(w-w_{s}^{(l)}\right) c^{(l)}}{\partial z}
$$

$$
-\frac{\partial}{\partial x}\left(\epsilon_{s, x}{ }^{(l)} \frac{\partial_{c}{ }^{(l)}}{\partial x}\right)-\frac{\partial}{\partial y}\left(\epsilon_{s, y}{ }^{(l)} \frac{\partial_{c}{ }^{(l)}}{\partial y}\right)-\frac{\partial}{\partial z}\left(\epsilon_{s, z}{ }^{(l)} \frac{\partial_{c}{ }^{(l)}}{\partial z}\right)=0
$$

where $c^{(l)}$ is the mass concentration of the sediment fraction $(l) ; ; \epsilon_{s, x}{ }^{(l)}, \epsilon_{s, y}{ }^{(l)}, \epsilon_{s, z}{ }^{(l)}$ stands for eddy diffusivities of the sediment fraction $(l)$; finally, $w_{S}{ }^{(l)}$ is the sediment settling velocity of the sediment fraction $(l)$. The local flow velocities and eddy diffusivities are computed by the hydrodynamic model. The sediment transport is computed in the same way as the transport of any other constituent (e.g. salinity or temperature); nevertheless, there exist a number of important differences between sediments and other constituents - exchange of sediment between the bed and the flow, or parameters such as the settling velocity, whose appropriate computation is of major importance for obtaining accurate results (Deltares, 2011).

The effect of sediments on fluid density is considered by using the empirical relationship formulated by UNESCO (Unesco, 1981) which accounts for the varying temperature and salinity. In the case of the sediment transport, this relationship is 
extended in order to consider the density effect of sediment fractions in the fluid mixture. For this purpose the mass of the different sediment fractions is added and the displaced water mass subtracted. This can be expressed as:

$$
\rho_{\text {mix }}\left(S, c^{(l)}\right)=\rho_{w}(S)+\sum_{l=1}^{l s e d} c^{(l)}\left(1-\frac{\rho_{w}(S)}{\rho_{s}^{(l)}}\right)
$$

217 where $\rho_{w}(S)$ is the specific water density with salinity concentration $S ; \rho_{S}{ }^{(l)}$ is the 218 specific density of the sediment fraction $(l)$; finally lsed is the number of sediment 219 fractions.

The settling velocity for non-cohesive and cohesive sediment fractions is computed with different formulations. In the case of non-cohesive sediments the Van Rijn method is 222 implemented (Van Rijn, 1993), which depends on the diameter of the sediment in 223 suspension:

$224 \quad w_{s, 0}^{(I)}=\left\{\begin{array}{lr}\frac{\left(s^{(I)}-1\right) g D_{s}^{(I) 2}}{18 v}, & 65 \mu m<D_{s} \leq 100 \mu m \\ \frac{10 v}{D_{s}}\left(\sqrt{1+\frac{0.01\left(s^{(I)}-1\right) g D_{s}^{(I) 3}}{v^{2}}-1}\right), & 100 \mu m<D_{s} \leq 1000 \mu m \\ 1.1 \sqrt{\left(s^{(l)}-1\right) g D_{s}^{(l)}}, & 1000 \mu m<D_{s}\end{array}\right.$

225 where $s^{(l)}$ is the relative density of sediment fraction $(l)\left(s^{(l)}=\frac{\rho_{s}{ }^{(l)}}{\rho_{w}}\right), D_{s}{ }^{(l)}$ accounts for 226 the representative diameter of the sediment fraction $(l)$, and $v$ stands for the kinematic 227 viscosity coefficient of water.

228 With respect to the cohesive sediment fraction, a complex formulation is used which 229 includes the computation of two settling velocities, for fresh water and salt water. For 
230 full details about the methodology for modelling this and other processes related to the

231 cohesive sediment fraction, such as dispersion, erosion or deposition, the reader is 232 referred to Delft Flow Manual (Deltares, 2011).

\subsection{Model implementation}

234 In the present study, and following previous works on the hydrodynamics of this ria

235 (Ramos et al., 2013), the hydrodynamic and sediment transport model is implemented in 236 its 2D form with a high spatial resolution (Periáñez et al., 2013). Given that the aim of 237 this research is to conduct an accurate assessment of the morphological evolution of the approach channel over a 4-year period, the numerical grid (Figure 5) covers not only the area of interest (the middle ria) but the entire estuary (including the inner and outer ria), whose morphodynamics may affect the bedload sediment transport in the channel. The resolution within the ria is set to $40 \mathrm{~m}$, with the size of the cells increasing progressively towards the sea boundary, which is located sufficiently distant that numerical disturbances do not affect the area of interest. 


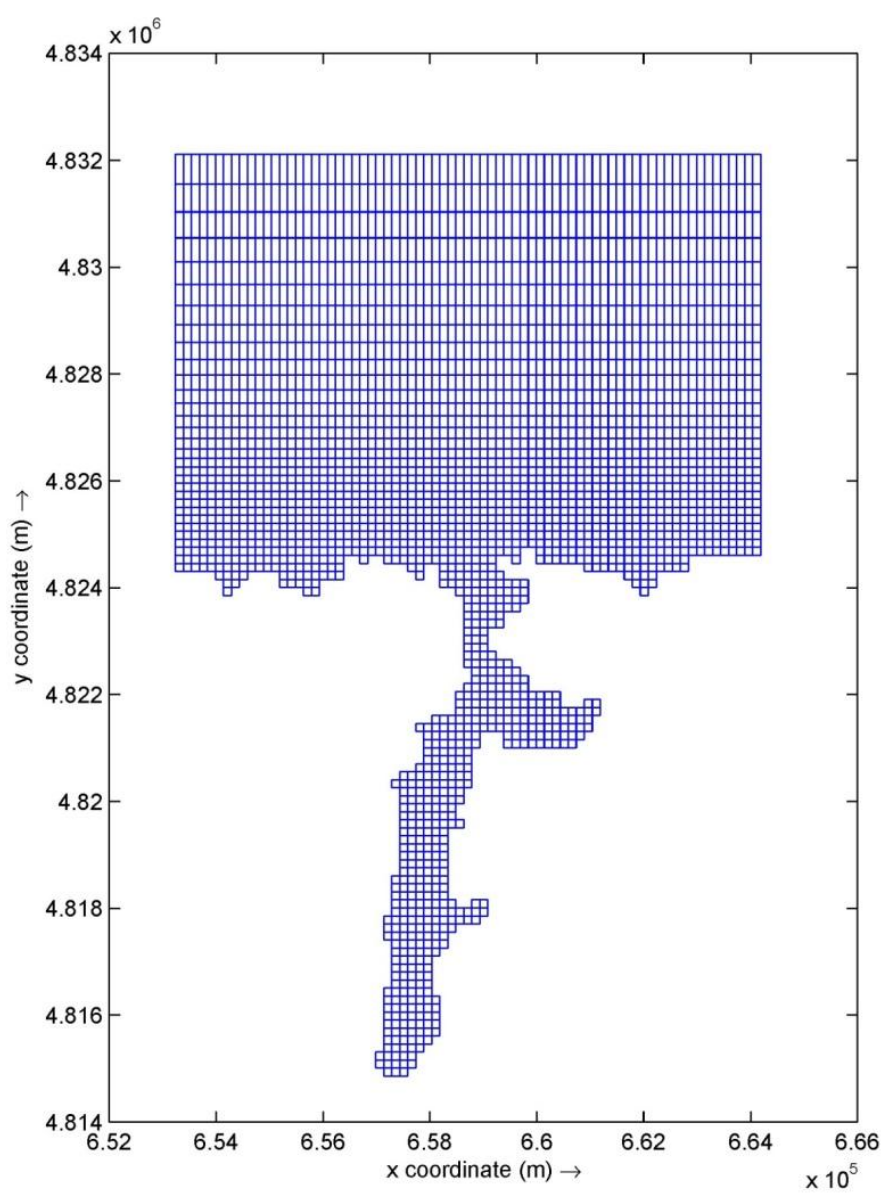

254 Figure 5. Numerical grid used for hydro-morphodynamic computations. For clarity only

2551 in 4 grid lines are plotted.

256 The bathymetric data of the ria and the adjoining continental shelf (Figure 6) are

257 obtained from the relevant nautical charts, which are digitised and interpolated onto the

258 computational grid. In addition, the most recent bathymetric data from previous

259 dredging operations in the approach channel were also included in the numerical grid.

260 Finally, the intertidal areas are modelled by considering topographic data with $5 \mathrm{~m}$ of

261 resolution. Given that this ria presents large shallow areas, a spatially varying value of

262 the Manning coefficient, $n$, is input to the model, defined as a function of the water depth (Table 3) (e.g. Cheng et al., 1993; Dias and Lopes, 2006). 


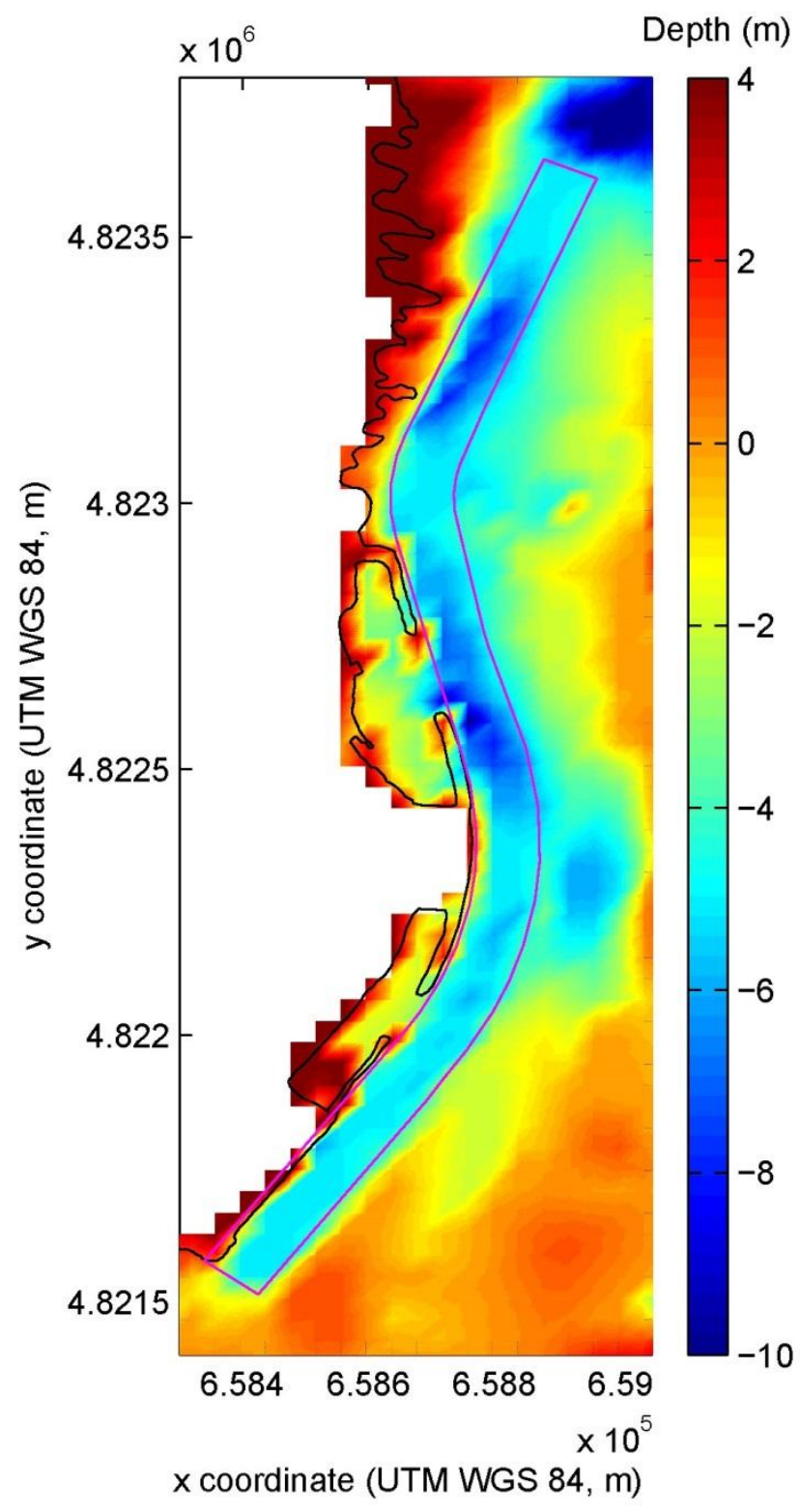

Figure 6. Bathymetry of the area of study. 


\begin{tabular}{cc}
\hline $\boldsymbol{d}(\mathbf{m})$ & $\boldsymbol{n}$ \\
\hline$d<-2.0$ & 0.042 \\
$-2.0 \leq d<-1.5$ & 0.038 \\
$-1.5 \leq d<-1.0$ & 0.034 \\
$-1.0 \leq d<-0.5$ & 0.030 \\
$-0.5 \leq d<0.0$ & 0.027 \\
$0.0 \leq d<0.5$ & 0.024 \\
$0.5 \leq d<1.0$ & 0.022 \\
$1.0 \leq d<3.0$ & 0.020 \\
$3.0 \leq d<10.0$ & 0.018 \\
$d>10$ & 0.015 \\
\hline
\end{tabular}

The turbulent eddy viscosity, $v$, and diffusivity, $D$, are calibration parameters. For the calibration, field data of water levels and currents measured by an Acoustic Doppler

277 Profiler (ADCP) (location ADCP 2, Figure 1) during three weeks (from $16^{\text {th }}$ of October 2782011 to $4^{\text {th }}$ of November 2011) are compared with model data obtained with different 279 values of $v$ and $D$. The values of the correlation coefficient, $R$, for the horizontal velocities, $u$ and $v$ and water levels, $\eta$, are presented in Table 4. On the basis of these results, the turbulent eddy viscosity and diffusivity are set to $5 \mathrm{~m}^{2} \mathrm{~s}^{-1}$. Then, the 282 performance of the model using these values is checked at an additional location 283 (ADCP 1) for the same period (Table 5). The good agreement obtained between simulated and observed values shows that the model is capable of appropriately capturing the ria hydrodynamics. 
287 288

289

290

291

292

293 294

295

296

297
Table 4. Correlation coefficient, R, between simulated and observed data for different eddy viscosities and diffusivities at location ADCP 2.

\begin{tabular}{cccc}
\hline & \multicolumn{2}{c}{ Velocities correlation } & Sea level correlation \\
\cline { 2 - 4 } $\boldsymbol{v}, \boldsymbol{D}\left(\boldsymbol{m}^{\mathbf{2}} \boldsymbol{s}^{-\mathbf{1}}\right)$ & $\boldsymbol{R}_{\boldsymbol{U}}$ & $\boldsymbol{R}_{\boldsymbol{V}}$ & $\boldsymbol{R}_{\boldsymbol{\eta}}$ \\
\hline 1 & 0.8200 & 0.8912 & 0.9920 \\
5 & 0.9449 & 0.9710 & 0.9938 \\
15 & 0.9345 & 0.9294 & 0.9920 \\
30 & 0.9256 & 0.9277 & 0.9920 \\
50 & 0.9024 & 0.9177 & 0.9921 \\
100 & 0.8607 & 0.8933 & 0.9920 \\
\hline
\end{tabular}

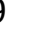




\subsection{Case study}

300 With the aim of analysing the evolution of the bathymetry of the approach channel 301 resulting from the complex morphodynamics of Ria de Ribadeo, the model is run for a 302 total of 4 years, from 2012 to 2016 . The initial date for the simulations corresponds to 303 the date when the last dredging was conducted and therefore accurate depth data of the 304 approach channel are available (which in turn is the initial depth considered for 305 numerical modelling).

306 All the relevant hydrodynamic and morphodynamic forcing factors are considered in the 307 simulation: tide, river discharges, and salinity and temperature at open boundaries, as 308 well as the spatial distribution of the sediments. The tide is introduced by considering 309 the values of the seven major tidal constituents provided by TPXO data (Egbert et al., 1994) (Table 6); river discharges are set to the mean historic discharge (April 2009 to December 2012) $\left(18,83 \mathrm{~m}^{3} \mathrm{~s}^{-1}\right)$; finally, the salinity and temperature at the open boundaries are computed through ROMS (Regional Ocean Modelling System) (Otero et al., 2008). Regarding the mophological data, the principal model forcing parameters considered are shown in Table 7 (Hu et al., 2009).

Table 6. Tidal constituents at the ocean boundary of the numerical grid.

\begin{tabular}{ccc}
\hline Constituent & Amplitude (cm) & Phase $\left(^{\circ}\right)$ \\
\hline $\mathrm{M}_{2}$ & 125.13 & 91.40 \\
$\mathrm{~S}_{2}$ & 43.96 & 112.17 \\
$\mathrm{~N}_{2}$ & 26.47 & 71.45 \\
$\mathrm{~K}_{2}$ & 12.27 & 120.23 \\
$\mathrm{~K}_{1}$ & 7.14 & 73.27 \\
$\mathrm{O}_{1}$ & 6.23 & 324.20 \\
$\mathrm{P}_{1}$ & 2.16 & 64.82 \\
\hline
\end{tabular}


318 Table 7. Principal morphological parameters used in the implementation of the 319 numerical model.

\begin{tabular}{cc}
\hline Parameter & Value \\
\hline Specific density $\left(\mathrm{Kg} / \mathrm{m}^{3}\right)$ & 2650 \\
Dry bed density $\left(\mathrm{Kg} / \mathrm{m}^{3}\right)$ & 1600 \\
Initial sediment layer at bed $(\mathrm{m})$ & 5 \\
Median sediment diameter $\left(\mathrm{D}_{50}\right)$ & Spatial distribution \\
\hline
\end{tabular}

322 With respect to the grain size, the ria has a complex distribution that must be 323 characterised if the evolution of the approach channel is to be appropriately modelled 324 (Flor et al., 1983; Encinar and Rodríguez, 1983; Flor et al., 1992). The spatial 325 distribution of the mean grain size diameter, $D_{50}$, is input to the model following 326 previous studies, and in particular using measured data (Figure 7) provided by the Port 327 Authority from the latest dredging operations. As a result, the configuration of the seabed in the channel and the sediment input to the model (Figure 8) correspond exactly with the initial data of the numerical simulation — a prerequisite for ensuring the accuracy of the model results. 


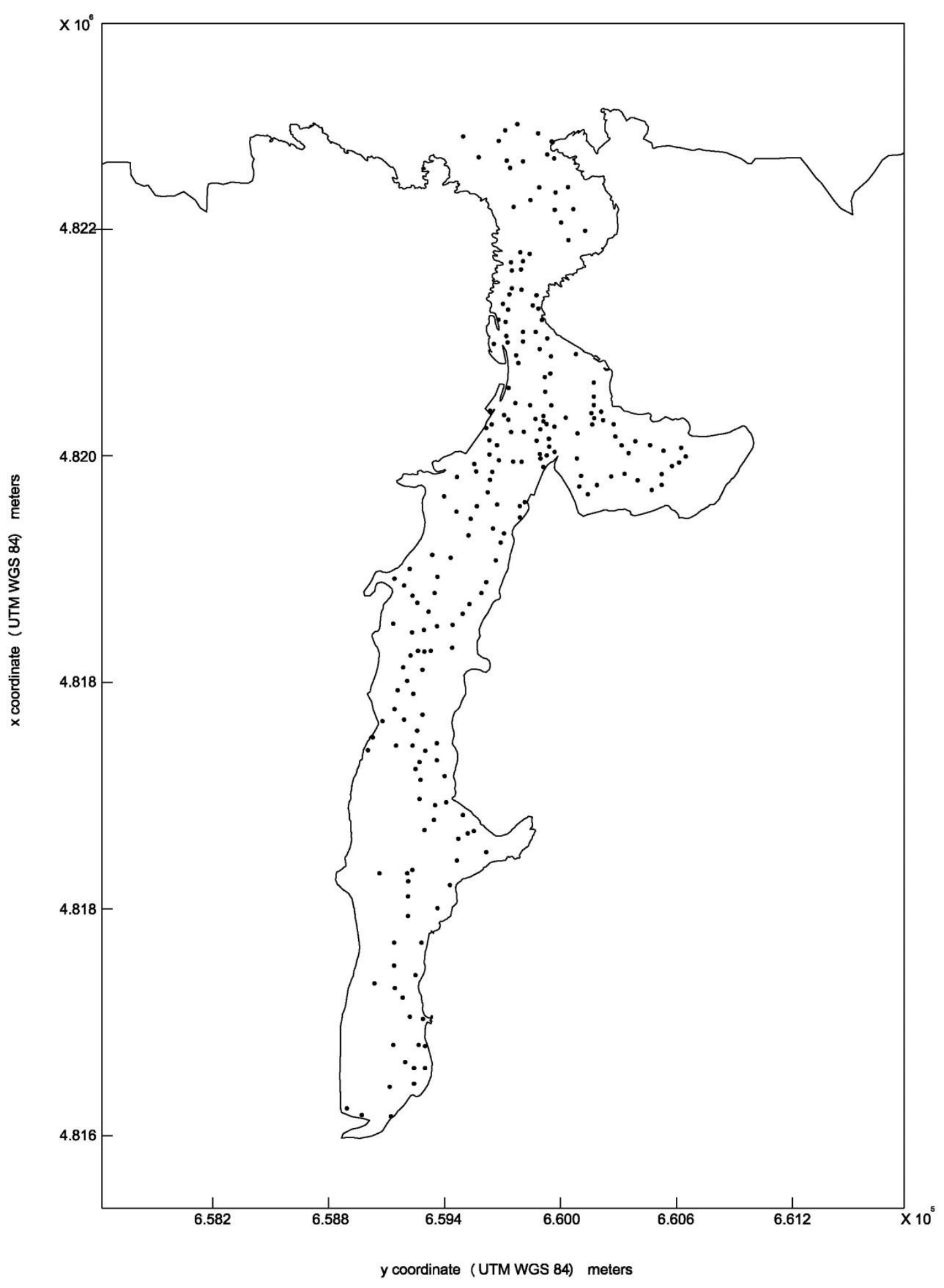

Figure 7. $D_{50}$ sampling stations. 


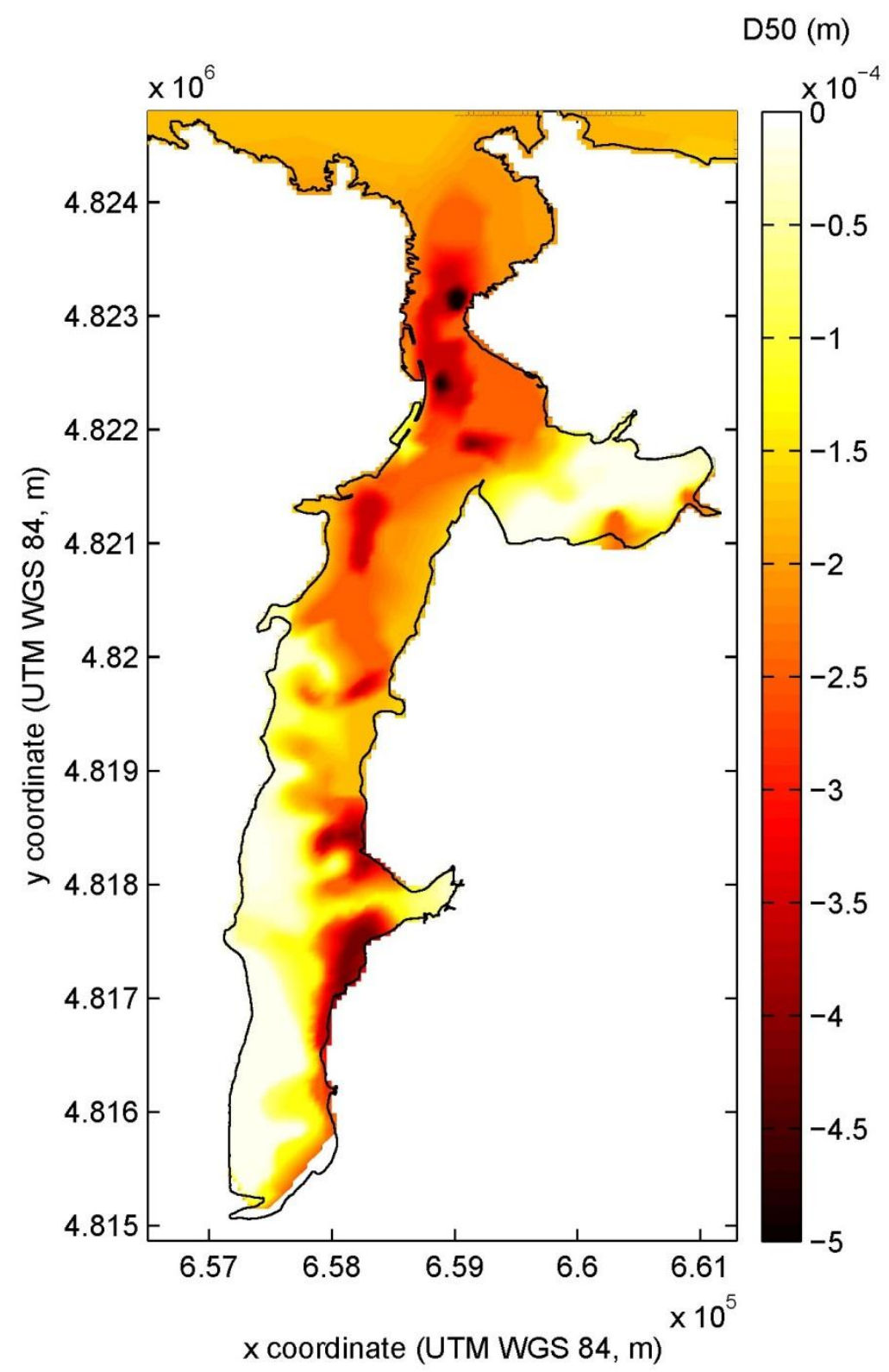

Figure 8. Spatial distribution of the mean grain size diameter, $\mathrm{D}_{50}$.

344 The model capability for predicting the evolution of the approach channel is analysed.

345 For this purpose, the seabed position computed by the model at the end of 4-year period 346 is compared with high-resolution in situ measurements in the area occupied by the 
347 approach channel and surroundings gathered at the end of model simulations (year

348 2016) (Figure 9). The correlation coefficient, R, between the bathymetry configuration 349 predicted by the model (left) and measured (right) is 0.71 .
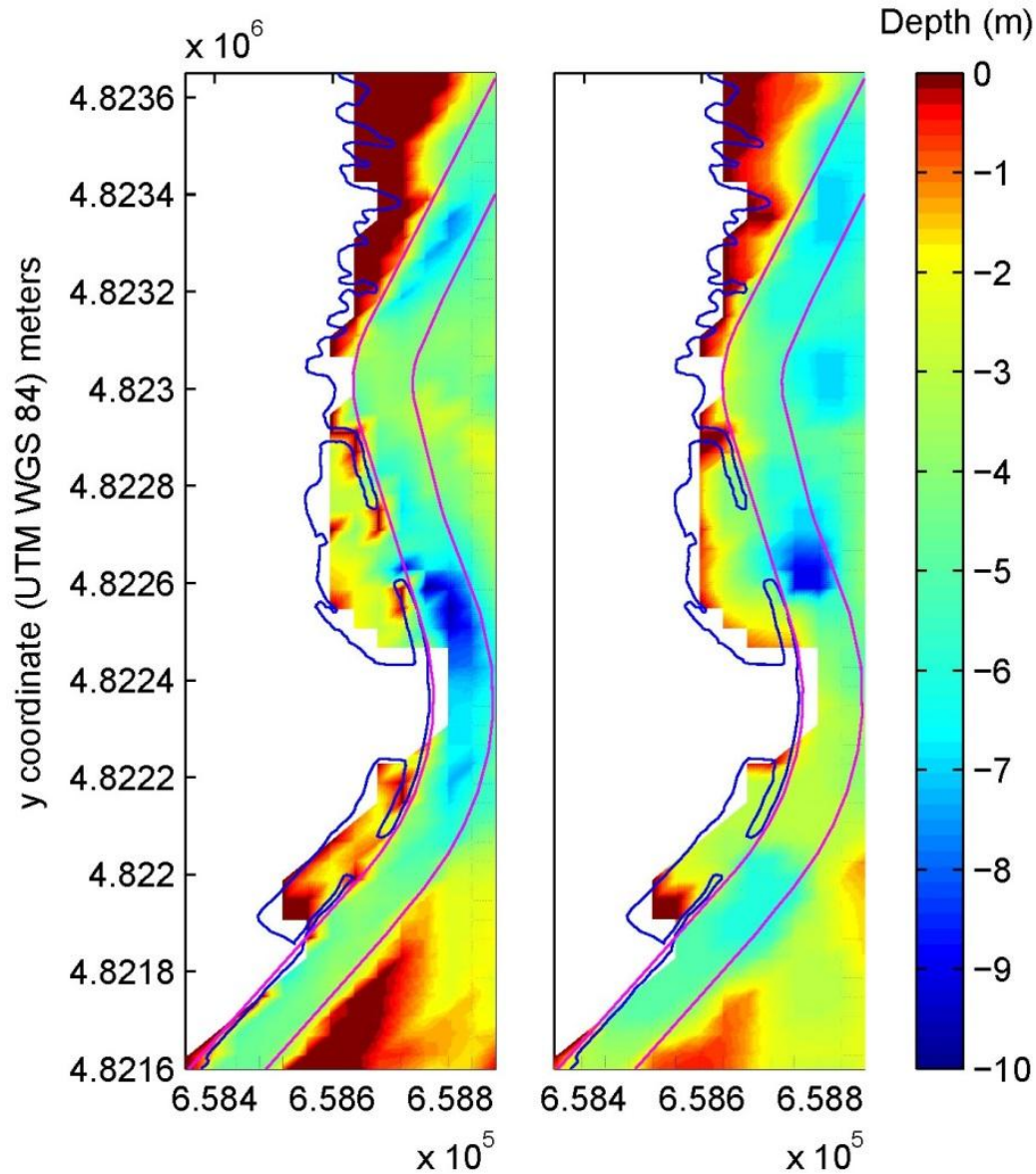

352 Figure 9. Bathymetry configuration computed by the model (left) and measured (right) 353 at the end of model simulations. 
355 The results obtained prove the ability of the model for accurately reproducing the

356 bathymetric trends in the approach channel, not least considering the complexity of the

357 problem.

\section{HYDROMORPHOLOGICAL RESULTS}

360

The hydrodynamic results obtained through numerical modelling clearly show the strong currents that occur in the ria, and in particular within the approach channel, which in part explain the need for frequent dredging discussed in the Introduction. In Figure 10 the flow velocities in the middle and outer Ria the Ribadeo are plotted during mid-flood and mid-ebb of a spring tide (10 March 2012). It can be observed that strong current velocities occur both during ebb and flood throughout the ria, and in particular within the approach channel, where velocity magnitudes exceed $1 \mathrm{~ms}^{-1}$ over large areas, reaching $1.5 \mathrm{~ms}^{-1}$ at specific locations. In addition, a tidal asymmetry can be observed, with larger velocities during flooding. This asymmetry, which has been observed in other Galician rias (Iglesias and Carballo, 2011; Iglesias and Carballo, 2010), which may contribute to sediment entrapment in the inner ria and, ultimately, to bedforms such as megaripples and sand banks. 
(a)

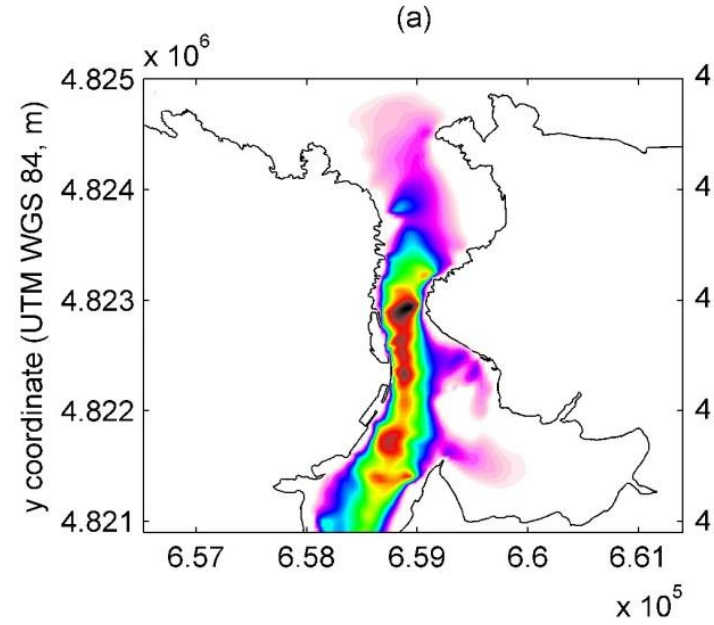

(b)

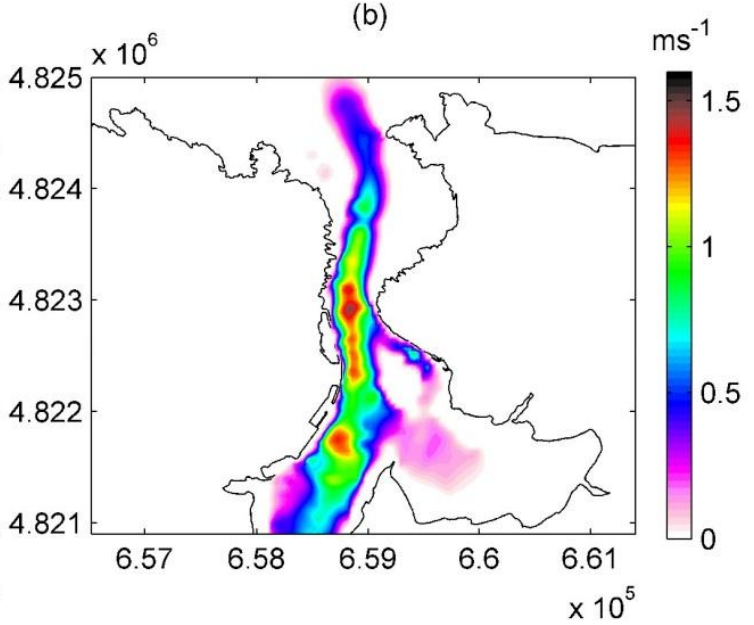

x coordinate (UTM WGS 84, m)

379 Figure 10. Mid-flood (a) and mid-ebb (b) depth-averaged flow velocities in the Ría of 380 Ribadeo.

381

382

These strong currents, as stated, generate an important transport of sediments resulting

383 in a significant variation of the bed configuration on this coastal area. In Figure $\mathbf{1 1}$ the evolution of the bed level over a 4-year period is shown. Overall, a relationship can be observed between current velocities and sediment transport, with accretion associated with the areas of weaker current velocities and erosion with those boasting stronger velocities. 


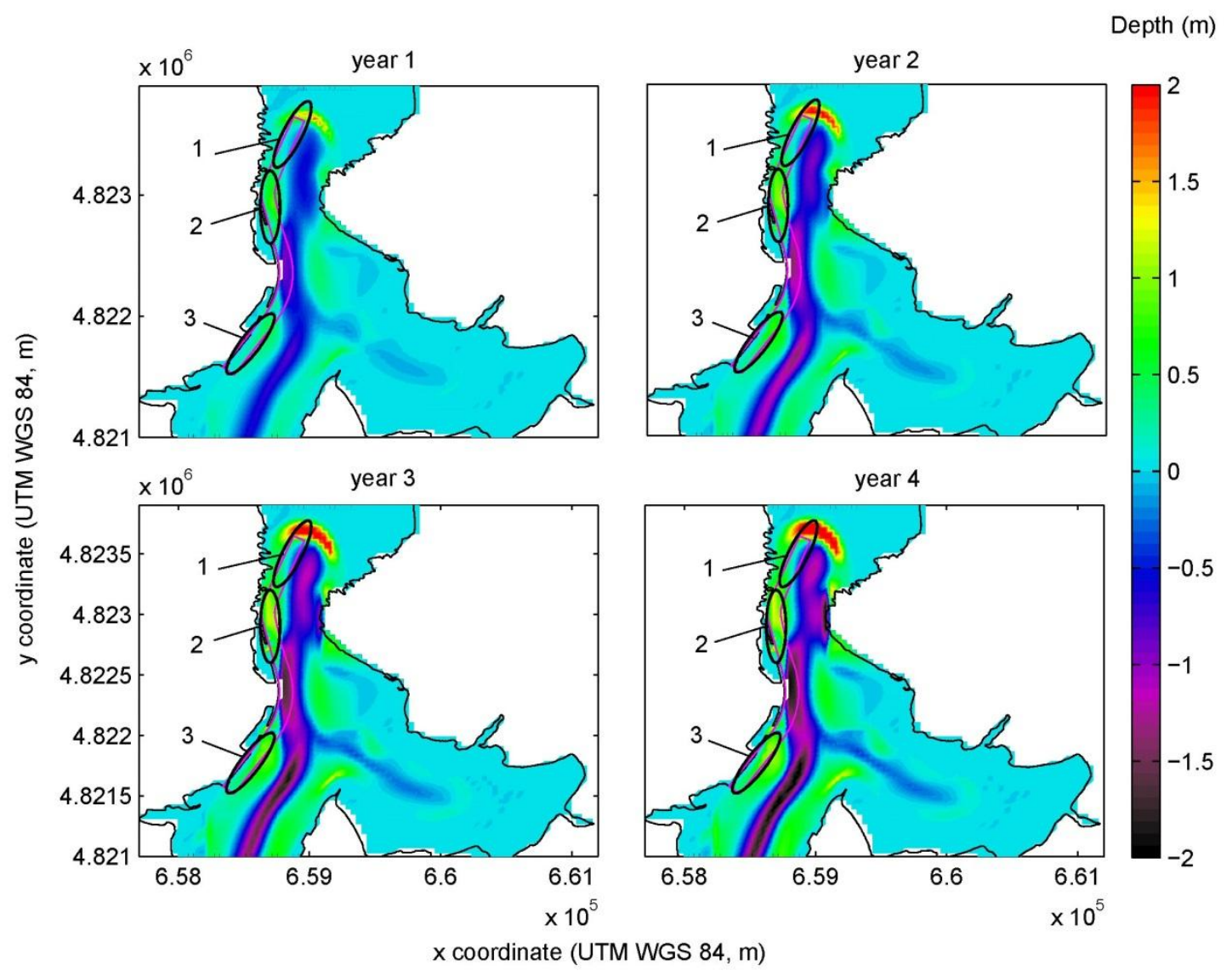

394 Figure 11. Bed update of the Ría de Ribadeo over a 4-year period (the approach channel

395 is represented with a red line). Positive and negative values indicate an increase and

396 reduction of the bed level, respectively.

In the case of the approach channel to the Port of Ribadeo defined in Section 2, three important accretion areas can be identified: (1) the outer approach channel, with accretion of up to $2 \mathrm{~m}$ at the end of the 4-year period analysed, (2) the area in front of the marina, with an increase in the seabed level of about of $1.5 \mathrm{~m}$, and (3) finally, a large area at the end of the channel (dockside), with less than $1 \mathrm{~m}$. Yet, their importance for the functioning of the port widely differs stemming from their total depth at the end 
of the 4-year period analysed, with more than $5 \mathrm{~m}$ in the case of the first area (1) and

405 less than $4-5 \mathrm{~m}$ in the second and third areas $(2,3)$ (Figure 12).Within the rest of the

406

407

408

409

410

411

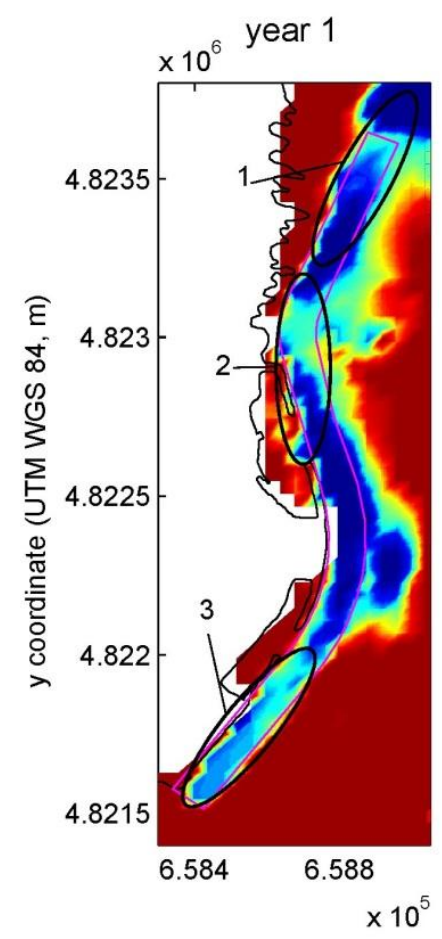

412

413

414 over the a 4-year period. channel (roughly the middle sections, corresponding to the area in front of the fishing port), significant erosion occurs which naturally does not pose a threat for the appropriate functioning of the port from a navigational standpoint. Still, this erosion can lead to scour problems at the breakwater, which was projected for a water depth of $5 \mathrm{~m}$ (LAT) and should be further analysed.

[FIGURE 12]
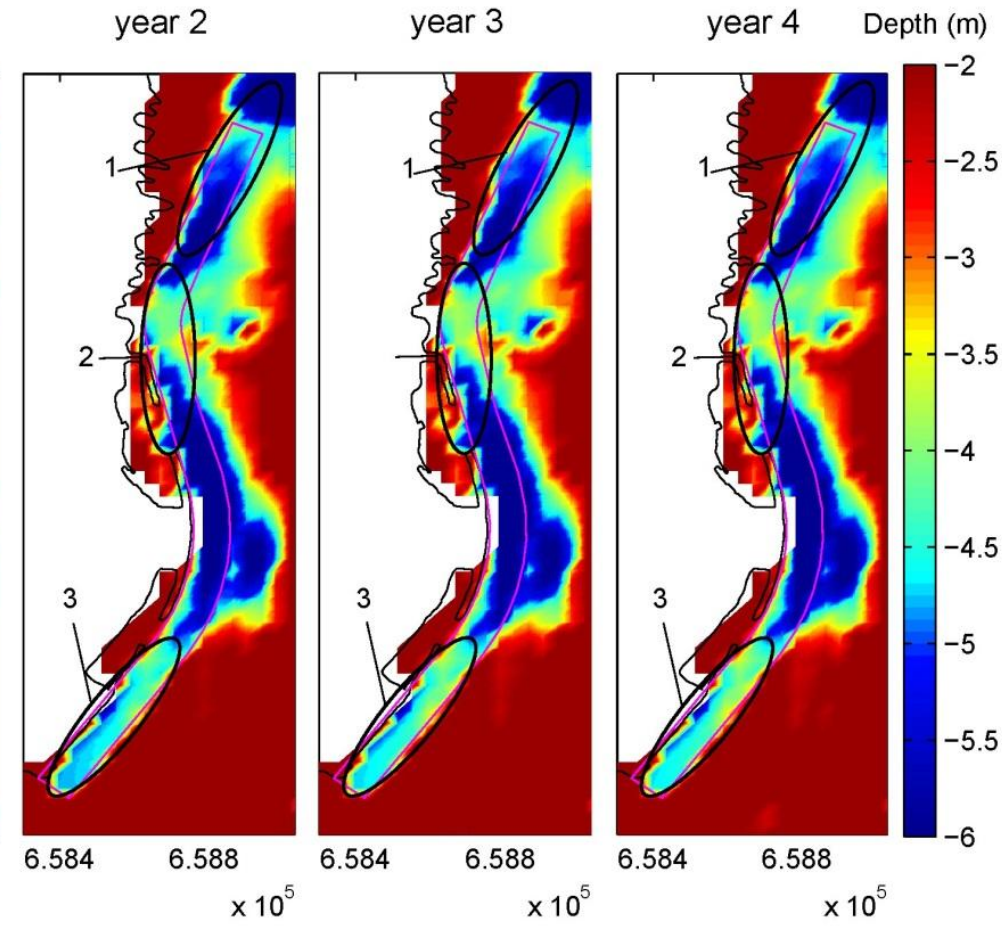

$\mathrm{x}$ coordinate (UTM WGS $84, \mathrm{~m}$ )

Figure 12. Evolution of the depth within the approach channel to the Port of Ribadeo 


\section{OPERATIVITY AND DREDGING: AN INTEGRATED APPROACH}

418 It has been shown that a total of $7.44 \mathrm{~m}$ is necessary for the design vessel to operate at 419 the Port of Ribadeo. Therefore, given that the water depth within the approach channel 420 cannot exceed $5 \mathrm{~m}$ (LAT) for constructive reasons, the required astronomical tidal level 421 is $2.44 \mathrm{~m}$ (Section 2). On this basis, the operativity can be computed, i.e. the period of

422

From the cumulative frequency of tidal levels, an annual figure of operativity of 4,025

[FIGURE 13]

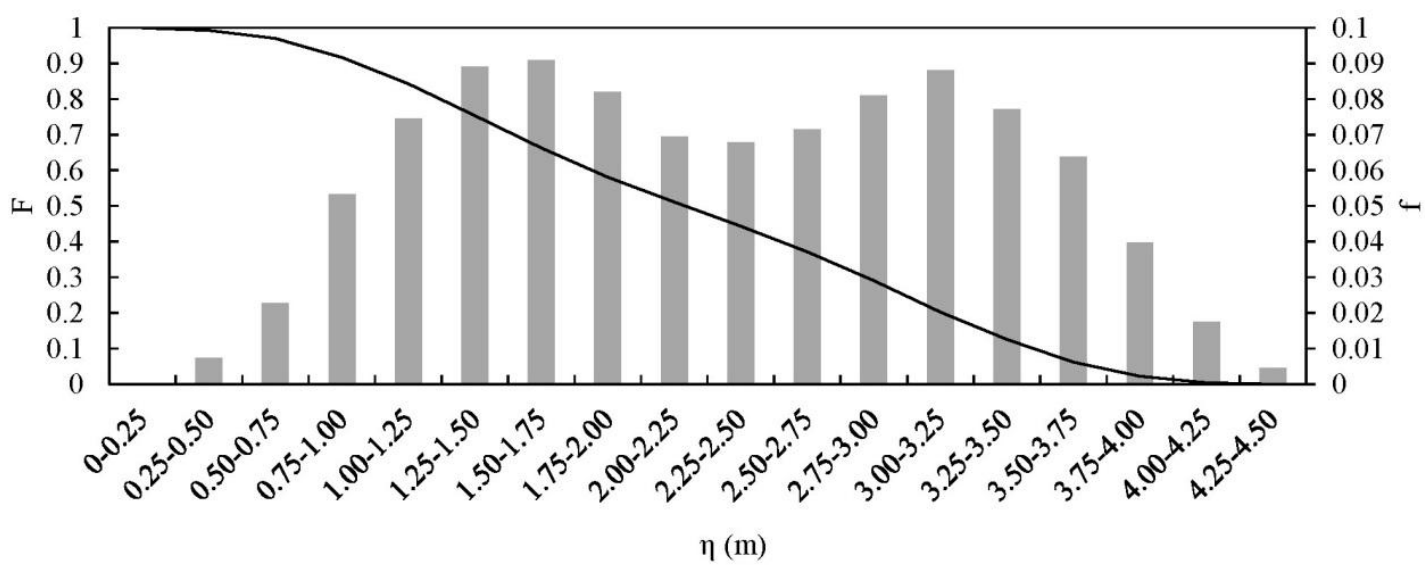

Figure 13. Annual discrete, $f$, and cummulative frequencies, $F$, of tidal level at the Port of Ribadeo computed through numerical modelling. $\mathrm{h} /$ year is obtained (operativity after dredging), i.e. the time during which the tidal level 
434 exceeds $2.44 \mathrm{~m}$. In addition, based on the results of the monthly cumulative frequencies,

435 the monthly operativity can be also computed. The corresponding results are shown in

436 Table 8. It emerges that the operativity is virtually constant throughout the year

437 resulting from the almost negligible intra-annual differences in the water level 438 distribution, thereby the dredging planning in the Port of Ribadeo can be determined on 439 the basis of annual figures of operativity.

\begin{tabular}{ccc}
\hline Month & Total hours & Operativity hours \\
\hline January & 744 & 341.5 \\
February & 672 & 309.5 \\
March & 744 & 342 \\
April & 720 & 331.5 \\
May & 744 & 341.5 \\
June & 720 & 329 \\
July & 744 & 343 \\
August & 744 & 340.5 \\
September & 720 & 331 \\
October & 744 & 342.5 \\
November & 720 & 330.5 \\
December & 744 & 342 \\
\hline
\end{tabular}


444 On the other hand, it has been shown (Section 4) that after dredging there are areas

445

446

447

448

449

450

451

452

453

454

455

456

457

458

459

460

461

462

463

464

465

466

467

468

within the approach channel where the depth is progressively reduced resulting from sediment transport, which in turn provokes a reduction of the operativity of the port. For technical and economic reasons, the operativity should never be less than 1,750 $\mathrm{h} /$ year, which corresponds to $20 \%$ of the time (Álvarez, 2013). On these grounds, the depth reduction allowing the minimum operativity level for a design vessel (requiring at least $7.44 \mathrm{~m}$ depth) is determined in this work. In the case of considering annual figures operativity is virtually constant throughout the year (Table 8) - the tidal level available for the design vessel at the operativity limit (1750 h/year) is $3.29 \mathrm{~m}$ (Figure 13), which corresponds with the required level for its operation. In addition, given that the design vessel requires a total of $7.44 \mathrm{~m}$, the operativity limit occurs when the depth within the approach channel is reduced to $4.15 \mathrm{~m}(7.44-3.29 \mathrm{~m})$. This means that the reduction of water depth resulting from sediment accretion should not exceed $0.85 \mathrm{~m}$ in the considered most restrictive locations — those originally set to $5 \mathrm{~m}$ depth after dredging.

Now, the 4-year hydro-morphodynamic high-resolution simulations are used so as to establish both the time point and location within the channel where this depth limitation $(4.15 \mathrm{~m})$ will firstly appear. From the numerical results, this limitation is determined to occur in first place in the area close to the marina (2) (Figure 12) in approximately 3.5 years after dredging. Furthermore, the numerical model results yields the high resolution bathymetry configuration of the seabed channel at the end of this period; therefore, the amount of sediments to be dredged so as to rise the operativity to a certain level can be accurately computed. In the present study if a new dredging is to be planned at the time point when the operativity limit is reached, a total of $145,760 \mathrm{~m}^{3}$ should be dredged for restoring the initial level of operativity established at 4,025 h/year. 
469 Given the complexity of the method developed, a flowchart containing the whole

470 procedure presented in this work and implemented in the Ria de Ribadeo is shown in

$471 \quad$ Figure 14.

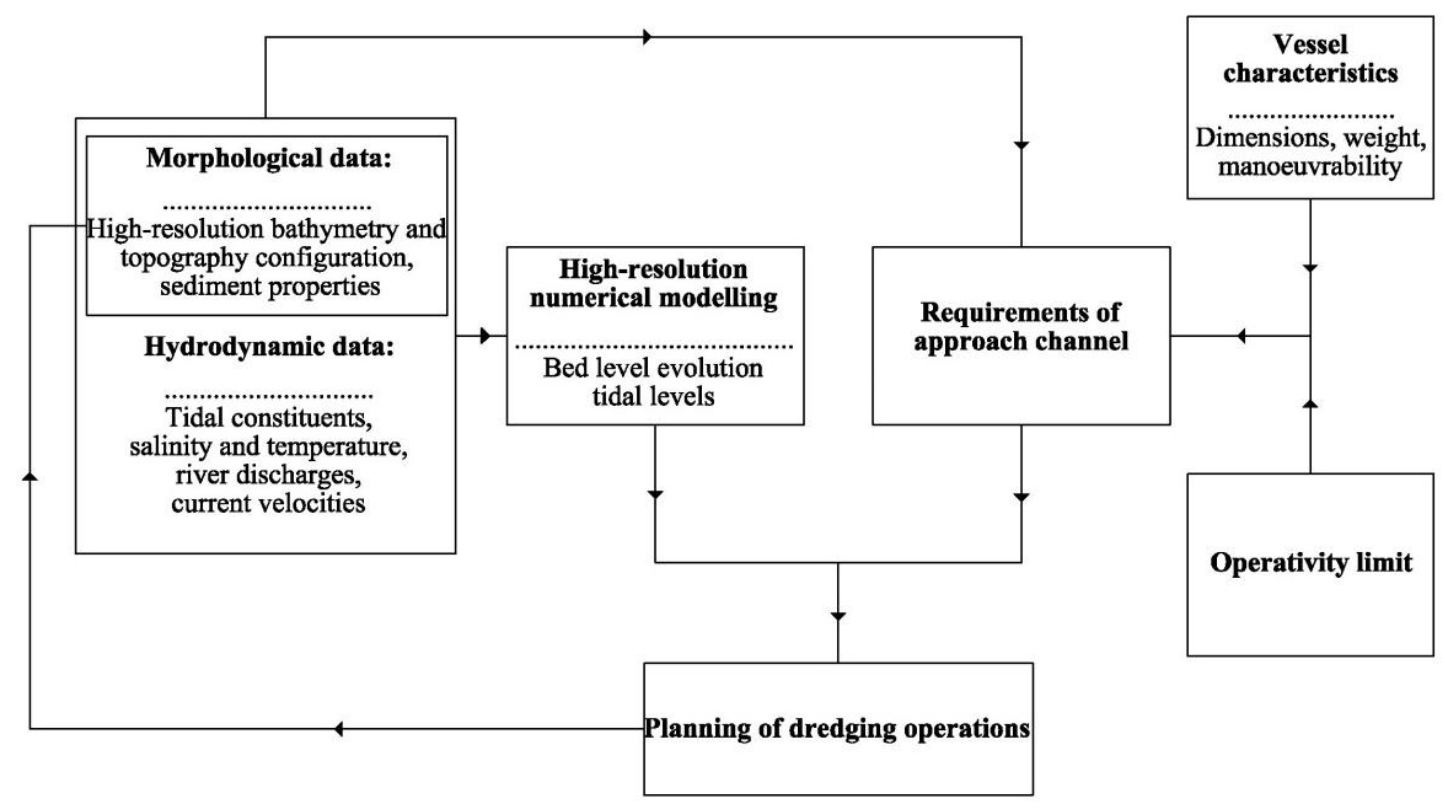

Figure 14. Flowchart of the decision-aid tool.

\section{CONCLUSIONS}

477 The Port of Ribadeo is the largest by trade volume of the ports managed by Ports of

478 Galicia Regional Authority. Owing to great importance for the region, a well-defined

479 plan for maintaining adequate levels of operativity is fundamental for it to continue

480 being a mainstay of the economic activity of the area. The complex morphodynamics of

481 the ria, characterised by intense sediment transport, has been shown to affect the approach channel, posing a threat to the operativity of the port. With this in view, in the 
developed and implemented to this coastal area. Based on a state-of-the-art numerical model, calibrated and validated with field measurements, together with accurate data of navigational requirements and tidal levels in the area, the implementation of this method provides the necessary information for conducting cost-effective dredging operations.

For this purpose, in the first place the dimensions of the approach channel to the Port of Ribadeo are accurately defined on the basis of a thorough analysis of the vessels operating in the area $-\mathrm{a}$ total width ranging from $90 \mathrm{~m}$ to $105 \mathrm{~m}$ depending on the section considered, and a minimum water depth of $7.44 \mathrm{~m}$. Given that the maximum depth of the approach channel could not exceed $5 \mathrm{~m}$ at some locations (roughly the area close to the trading port) so as to avoid undermining problems, a tidal level of 2.44 is necessary for the design vessel to operate in the area. Then, high resolution hydromorphodynamic computations are conducted with the aim of characterizing the time evolution of the bed configuration of the approach channel during a 4-year period (starting at the last dredging operation). The numerical results clearly show three areas of significant accretion (approx. 1-2 $\mathrm{m}$ at the end of the 4-year period analysed) but only two of them are critical for the appropriate functioning of the Port — roughly the areas located in front of the marina and the dockside.

The next step of the procedure consists in analysing the tidal level distribution so as to define the required level for maintaining the minimum operativity, which is established at $1,750 \mathrm{~h} /$ year. This analysis is conducted by determining the monthly and annual 504 frequencies of the tidal levels at the Port of Ribadeo which are computed in the present work through numerical modelling. From the results obtained it emerges that a tidal level of $3.29 \mathrm{~m}$ is required for achieving the operativity limit, i.e. the water depth within

507 the approach channel should not be less than $4.15 \mathrm{~m}$. 
508 Finally, the integration of the resulting information allows the determination of the time

509 point for conducting cost-effective dredging operations. It is found that the minimum

510 water depth $(4.15 \mathrm{~m})$ is firstly achieved in the area close to the marina, approximately

5113.5 years after the previous dredging. Furthermore, the present procedure also provides

512 a detailed bathymetric configuration of the channel and therefore the accurate

513 computation of the volume to be dredged for increasing the operativity up to a certain

514 level. In the case of the Port of Ribadeo, should the initial level of operativity is to be

515 restored $(4,025 \mathrm{~h}$ /year corresponding to the period during which at least a tidal level of

$5162.44 \mathrm{~m}$ is available), a total of $145,760 \mathrm{~m}^{3}$ would have to be dredged.

517 In sum, the proposed integrated approach herein presented can contribute to an 518 appropriate decision making for the planning of dredging operations in shallow water 519 areas such as estuaries. The procedure was illustrated through the case study of the Port 520 of Ribadeo, but it could be implemented elsewhere.

\section{Acknowledgments}

523 The authors are grateful to the Regional Authority Portos de Galicia and Germán Flor

524 for their essential contribution providing historical morphodynamic data of the Ria de 525 Ribadeo. During this work Miguel Álvarez has been supported by the I2C (Plan Galego 526 de Investigacion Innovación e Crecemento 2011-2015) of the Xunta de Galicia. 
531 Álvarez, M., 2013. Morphodynamic Analysis of the Ria De Ribadeo and its Influence

532 on the Shipping Operations. (in Galician). Universidad de Santiago de Compostela.

533 Briggs, M.J., Kopp, P.J., Silver, A.L., Wiggins, W., 2015. Probabilistic model for

534 predicting deep-draught channel design: Savannah, GA entrance channel. Ocean Eng. $535108,276-286$.

536 Carballo, R., Iglesias, G., Castro, A., 2009a. Numerical model evaluation of tidal stream

537 energy resources in the Ría de Muros (NW Spain). Renewable Energy 34, 1517-1524.

538 Carballo, R., Iglesias, G., Castro, A., 2009b. Residual circulation in the Ría de Muros

539 (NW Spain): A 3D numerical model study. Journal of Marine Systems 75, 130.

540 Cheng, R.T., Casulli, V., Gartner, J.W., 1993. Tidal, Residual, Intertidal Mudflat

541 (TRIM) Model and its Applications to San Francisco Bay, California. Estuarine, Coastal 542 and Shelf Science 36, 235-280.

543 Deltares, 2011. User Manual Delft3D-FLOW.Simulation of Multi-Dimensional

544 Hydrodynamic Ows and Transport Phenomena, Including Sediments., Deltares ed,

545 Delft, The Netherlands.

546 Dias, J.M., Lopes, J.F., 2006. Implementation and assessment of hydrodynamic, salt and 547 heat transport models: The case of Ria de Aveiro Lagoon (Portugal). Environmental 548 Modelling and Software 21, 1-15. 
549 Dias, J.M., Sousa, M.C., Bertin, X., Fortunato, A.B., Oliveira, A., Numerical modeling 550 of the impact of the Ancão Inlet relocation (Ria Formosa, Portugal). Environmental 551 Modelling \& Software In Press, Corrected Proof.

552 Egbert, G.D., Bennett, A.F., Foreman, M.G.G., 1994. Topex/Poseidon tides estimated 553 using a global inverse model. Journal of Geophysical Research 99, 24821-52.

554 Encinar, M., Rodríguez, G.F., 1983. Aportaciones Para El Conocimiento De La

555 Dinámica Y Sedimentación De La Ria Del Eo (Asturias-Galicia, NW De España).

556 Consejería de Agricultura y Pesca del Principado de Asturias.

557 Flor, G., Fernández-Pérez, L.A., Cabrera-Cenal, R., 1992. Caracteristicas dinamicas y 558 sus relaciones sedimentarias en la Ria del Eo (Galicia-Asturias, Noroeste de Espana).

559 Revista de la Sociedad Geologica Espahola 5, 7-25.

560 Flor, G., Pérez, L.F., Ceñal, R.C., 1983. Aspectos morfológicos del estuario del Eo.

561 Trabajos de Geología 19, 75-97.

562 García-Morales, R.M., Baquerizo, A., Losada, M.Á, 2015. Port management and 563 multiple-criteria decision making under uncertainty. Ocean Eng. 104, 31-39.

564 Hu, K., Ding, P., Wang, Z., Yang, S., 2009. A 2D/3D hydrodynamic and sediment 565 transport model for the Yangtze Estuary, China. J. Mar. Syst. 77, 114-136.

566 Iglesias, G., Carballo, R., 2011. Can the seasonality of a small river affect a large tide567 dominated estuary? The case of the Ria de Viveiro, Spain. Journal of Coastal Research $568 \quad 27,1170-1182$. 
569 Iglesias, G., Carballo, R., 2010. Effects of high winds on the circulation of the using a 570 mixed open boundary condition: the Ría de Muros, Spain. Environmental Modelling \& 571 Software 25, 455-466.

572 Iglesias, G., Carballo, R., 2009. Seasonality of the circulation in the Ría de Muros (NW 573 Spain). J. Mar. Syst. 78, 94-108.

574 Iglesias, G., Carballo, R., Castro, A., 2008. Baroclinic modelling and analysis of tide575 and wind-induced circulation in the Ría de Muros (NW Spain). Journal of Marine 576 Systems 74, 475-484.

577 López, I., López, M., Iglesias, G., 2015. Artificial neural networks applied to port 578 operability assessment. Ocean Eng. 109, 298-308.

579 López, M., Iglesias, G., 2013. Artificial Intelligence for estimating infragravity energy 580 in a harbour. Ocean Eng. 57, 56-63.

581 Otero, P., Ruiz-Villarreal, M., Peliz, A., 2008. Variability of river plumes off Northwest 582 Iberia in response to wind events. Journal of Marine Systems 72, 238-255.

583 Periáñez, R., Casas-Ruíz, M., Bolívar, J., 2013. Tidal circulation, sediment and 584 pollutant transport in Cádiz Bay (SW Spain): A modelling study. Ocean Eng. 69, 60585 69.Prumm, M., Iglesias, G., 2016. Impacts of port development on estuarine 586 morphodynamics: Ribadeo (Spain). Ocean Coast. Manage. 130, 58-72.

587 Puertos del Estado, 1999a. Part 7: Cross section requirements, in Puertos del Estado 588 (Ed.), Recommendations for Maritime Works (Spain) ROM 3.1-99: Designing 589 Maritime Configuration of Ports. 

Puertos del Estado, 1999b. Recommendations for Maritime Works (Spain) ROM 3.199: Designing Maritime Configuration of Ports.

592

Ramos, V., Carballo, R., Álvarez, M., Sánchez, M., Iglesias, G., 2013. Assessment of the impacts of tidal stream energy through high-resolution numerical modeling. Energy 594 $61,541-554$

Rosa-Santos, P., Veloso-Gomes, F., Taveira-Pinto, F., Silva, R., Pais-Barbosa, J., 2009.

Evolution of coastal works in Portugal and their interference with local

597 morphodynamics. J. Coast. Res., 757-761.

Sánchez, M., Iglesias, G., Carballo, R., Fraguela, J.A., 2013. Power peaks against installed capacity in tidal stream energy. IET Renewable Power Generation 7, 246-253. turbines for tidal stream energy: A comparative impact assessment. Energy 72, 691-701.

602 Sutulo, S., Rodrigues, J., Soares, C.G., 2010. Hydrodynamic characteristics of ship 603 sections in shallow water with complex bottom geometry. Ocean Eng. 37, 947-958. of the impact of breakwaters under construction on a sand spit area (Douro River estuary). Journal of Coastal Conservation 18, 177-191.

607 Unesco, 1981. Background Papers and Supporting Data on the Practical Salinity Scale 608 1978-Unesco. 